\title{
Article
}

2020/44

\section{The (Non)Application of the Posting of Workers Directive to Aircrew: How a lack of legal certainty leads to a failure to apply the posting rules in the aviation industry}

\section{CONTRIBUTORS Gautier Busschaert and Pieter Pecinovsky*}

\section{Introduction}

With Directive 96/71/EC of 16 December 1996 concerning the posting of workers in the framework of the provision of services (hereafter the 'Directive' or the 'Posting of Workers Directive'), the EU laid down the applicable rules for the working conditions of workers who were posted by their employers in another EU Member State. ${ }^{1}$ On the one hand, the EU wanted to protect the posted workers against being exploited by their posting employers and, on the other hand, it wanted to give the hosting Member States a tool against social dumping by employers who are sending their workforce from Member States with lower wages and less protective labour conditions to Member States with higher wages and better labour conditions. However, the enlargement towards new Member States (especially during the 2000's) has brought the issue of social dumping back on the agenda of the EU, indicating among others difficulties with the application and enforcement of the posting rules.

Gautier Busschaert (PhD) is senior associate at the Brussels law firm Van Olmen \& Wynant. Pieter Pecinovsky (PhD) is counsel at the Brussels law firm Van Olmen \& Wynant.

1. Directive 96/71/EC of the European Parliament and of the Council of 16 December 1996 concerning the posting of workers in the framework of the provision of services, as revised by Directive (EU) 2018/957 of the European Parliament and of the Council of 28 June 2018 amending Directive $96 / 71 /$ EC concerning the posting of workers in the framework of the provision of services.
This article focuses on the posting of workers in the aviation industry. The main problem is that it is not clear in which situations the Posting of Workers Directive should be applied to aircrew (i.e. cabin crew and pilots). The aviation sector is characterised by a very mobile workforce in which it is possible for employees to provide services from different countries in a very short timeframe. This makes it, to a certain extent, easier for employers to choose the applicable social legislation, which can lead to detrimental working conditions for their aircrew. This article looks into how the Posting of Workers Directive can prevent some air carriers from unilaterally determining the applicable social legislation and makes some suggestions to end unfair social competition in the sector. This article is based on a research report which the authors drafted in 2019 with funding from the European Commission (hereafter the 'Report'). ${ }^{2,3}$

Should aircrew be declared posted? When, when not? In our opinion, answering this research question requires (i) determining the situations in which aircrew are posted (or not) and the obligations which would arise from such a posting considering the specificities of the aviation sector; (ii) assessing the suitability of the legislative framework based on, among others, input from members of the participating organisations; and (iii) formulating recommendations, if any, for adapting the legislative framework to these specificities.

The Report has drawn on information from questionnaires filled in by national legal experts and is further supported by an overview of the most relevant and recent studies and reports with regards to posting in the aviation sector. In this way, the Report, which this article summarises and brings up to date, forms a decent picture of the current situation with regards to the actual application of the posting rules to aircrew. Based on the legislative framework and the information gath-

2. In 2019, the authors' law firm, Van Olmen \& Wynant, was selected to provide a legal report on the application of the EU posting rules to aircrew. Three social partner organisations in the EU Sectoral Social Dialogue Committee on Civil Aviation applied for funding of the EU Commission under the EU call for proposal 'support for social dialogue' for a project entitled 'Should aircrew be declared posted? When, when not?' (grant VS/2019/0030). The social partners considered that, to progress in their social dialogue work on this matter, an external report by legal practitioners was necessary. The authors submitted the Report at the end of 2019 to the EU Sectoral Social Dialogue Committee on Civil Aviation. The social partners have added their comments and recently submitted it to the EU Commission for consideration of the regulatory steps that might be needed. The full report can be consulted at https:// www.vow.be/node/182

3. Please use the following full reference for this report: G. Busschaert and P. Pecinovsky, 'The application of the EU posting rules to aircrew', Van Olmen \& Wynant Report, 2019. 
ered from the (legal experts in the) Member States and the aforementioned studies, the Report also identifies the situations of employment which fall and those that do not fall under the scope of the Posting of Workers Directive.

Whether the application of the posting rules would be appropriate or suitable for each situation is assessed in view of three guiding values:

- Legal certainty: can national employment (and social security) rules applicable to the flying staff be easily predicted? Do these national rules remain applicable over time or are they everchanging depending on the country of posting?

- Feasibility: do the existing rules lead to red tape administrative obligations, which, taken the high amount of flights (possible postings), would lead to an excessive amount of formalities for airline companies?

- Fight against social dumping and unfair competition: related to the first value, can national employment rules applicable to the flying staff be objectively identified? Or can they be freely chosen by the airline companies, allowing forum shopping for the least protective rules?

\section{The situation in the Member States}

When preparing the Report, we have interviewed legal experts of all EU Member States and the UK about the application of the Posting of Workers Directive in their country and specifically with regards to the application of these rules to aircrew. ${ }^{4}$

First of all, it is remarkable that some Member States, amongst which Poland, Cyprus, Slovenia and Hungary, officially or in practice, hold the view that the Posting of Workers Directive is not applicable to aircrew. ${ }^{5}$ This interpretation seems to be in contrast with the intentions of the EU legislator and does not find any ground in the Posting of Workers Directive. Also other, more limited, exemptions (e.g. for a posting of less than 30 days in Spain) could cause aircrew not to fall under the posting rules in some Member States while they would in others. ${ }^{6}$ Nonetheless, when the posting rules are applied, the Member States would seem to apply the full set of hard-core labour law provisions as foreseen by Article 3.1 of the Posting of Workers Directive.

Secondly, the Enforcement Directive of 2014 has clearly reinforced compliance, as most Member States have established certain enforcement mechanisms and instruments as a result. ${ }^{7}$ The prior declaration of the posting,

4. For the methodology and full results of these interviews, we kindly refer to the Report.

5. Report, pp. 41-42.

6. Report, pp. 42-44.

7. Directive 2014/67/EU of the European Parliament and of the Council of 15 May 2014 on the enforcement of Directive 96/71/EC concerning the posting of workers in the framework of the provision of services and the obligation to keep social documents available and the designation of a liaison officer are common measures among Member States. Nonetheless, there are Member States who are still lagging behind. ${ }^{8}$

Thirdly, the general lack of data on the control and enforcement of the posting rules in the aviation industry and the information received from the national authorities via the national experts seem to indicate that the application of the posting rules in the aviation industry is not really a priority in most of the Member States. ${ }^{9}$ Also case law on the posting of aircrew is very rare, even if there is some interesting case law at national and EU level (e.g. Vueling $\left.^{10}\right) .{ }^{11}$

\section{Previous research}

In general, there is a lack of legal and scientific literature on the specific topic of posting of workers in the aviation sector. However, several useful and recent reports and studies that are relevant for our research exist, amongst others: ${ }^{12}$

- The Atypical Employment in Aviation Report of 2015 by researchers of Ghent University, commissioned by the European Cockpit Association, the Association of European Airlines and the European Transport Federation (financed by the European Social Dialogue Committee). ${ }^{13}$

- The Reports on A1 Portable Documents issued in 2016, 2017 and 2018 (Posting of Workers) undertaken by HIVA $^{14}$ as commissioned by the European Commission (Directorate-General for Employment, Social Affairs and Inclusion). ${ }^{15}$ This is a yearly

amending Regulation (EU) No. 1024/2012 on administrative cooperation through the Internal Market Information System ('the IMI Regulation') (hereafter the 'Enforcement Directive').

8. Report, pp. 47-52.

9. Report, pp. 53-55.

10. CJEU 2 April 2020, C-370/17 and C-37/18, Caisse de retraite du personnel navigant professionnel de l'aéronautique civile (CRPNPAC) - $v$ - Vueling Airlines SA en Vueling Airlines SA - v - Jean-Luc Poignant, ECLI:EU:C:2020:260. In these joined cases the CJEU has confirmed the conditions for national courts to set aside the binding force of A1 declarations in case of fraud.

11. Report, pp. 55-58.

12. Other studies on aviation in the EU, but less relevant for the topic, are Steer, Davies and Gleave, 'Study on the effects of the implementation of the EU aviation common market on employment and working conditions in the air transport sector over the period 1997/2010', July 2012 and Steer, Davies and Gleave, 'Study on employment and working conditions in air transport and airports', October 2015.

13. Y. Jorens, D. Gilis, L. Valcke and J. De Coninck, 'Atypical forms of employment in the aviation sector', European Social Dialogue, European Commission 2015.

14. HIVA, Research Institute for Work and Society is a multidisciplinary research institution at KU Leuven (Belgium).

15. F. De Wispelaere and J. Pacolet, 'Posting of workers, Report on A1 Portable Documents issued in 2016', EU Commission, December 2017; F. De Wispelaere and J. Pacolet, 'Posting of workers, Report on A1 Portable Documents issued in 2017', EU Commission, December 2018; F. De Wispelaere, L. De Smedt and J. Pacolet, 'Posting of workers, Report on A1 Portable Documents issued in 2018', EU Commission, October 2019. 
report on the amount of A1 declarations in light of the Social Security Coordination rules.

- The 2019 Ricardo Study, ordered by the European Commission (DG MOVE), provides insight into the working conditions of aircrews in the European internal market. ${ }^{16}$

- A 2019 European Commission Report on the Aviation Strategy for Europe: Maintaining and promoting high social standards. ${ }^{17}$

It is possible to draw some conclusions from these documents which are for the main part the same as those which resulted from the answers to our questionnaire by experts from the EU Member States.

First, the aviation sector resorts to complicated forms of employment with lots of intermediary structures, temporary agency work and other atypical contractual mechanisms, like wet leasing.

Second, according to the Ricardo Study, the actual amount of aircrew which in principle could fall under the scope of the Directive is $6 \%$ of the cabin crew and $12 \%$ of the pilots. Posting of workers is not very common, but it is also not a practice to be overlooked. Moreover, from the HIVA Reports on A1 Portable Documents as well as from the answers of the relevant interviewees in the Ricardo Study it is very clear that the actual application of the Posting of Workers Directive is way lower than $6 \%$ (cabin crew) or $12 \%$ (pilots). There seems to be a general lack of awareness of the posting rules.

228 Third, the Ricardo Study and the 2019 Aviation Strategy of the Commission have identified three instances in which the Posting of Workers Directive should in principle apply (transnational provision of services by temporary employment agencies or placement agencies; wet leasing; temporary assignment of aircrew to a secondary base outside their home base). In addition, the Ricardo Study also tries to identify the situations which should not fall within the scope of the Directive.

\section{Home base and secondary base}

Before presenting the core findings of the Report, it is useful to clarify two important concepts which are used in the evaluation of the different situations which fall and which do not fall under the scope of the Posting of Workers Directive.

First, there is the concept of home base: the 'home base' is a legal concept which is used in several EU legal

16. Ricardo Energy \& Environment, Study on employment and working conditions of aircrews in the EU internal aviation market, DG MOVE/ E1/2017-556, January 2019, further referred to as 'Ricardo Study $2019^{\prime}$.

17. European Commission, Aviation Strategy for Europe: Maintaining and promoting high social standards, $\operatorname{COM}(2019) 120$ final, Brussels, 1 March 2019. norms. However, our concept of home base is wider than the specific legal concept under EU law.

In the first place, the concept of 'home base' comes from EU social security law. Article 11(5) of Regulation $883 / 2004^{18}$ provides that "an activity as a flight crew or cabin crew member performing air passenger or freight services shall be deemed to be an activity pursued in the Member State where the home base, as defined in Annex III to Regulation (EEC) 3922/91, is located". This Annex III defines the 'home base' as "the location nominated by the operator to the crew member from where the crew member normally starts and ends a duty period or a series of duty periods and where, under normal conditions, the operator is not responsible for the accommodation of the crew member concerned" [emphasis added]. ${ }^{19}$ The home base is to be established taking into consideration the pattern and frequency of flight duties, with the objective of providing crew members with adequate and appropriate resting periods in compliance with the aforementioned provisions. This concept of 'home base' is not only used to determine the applicable social security legislation, but it is also a concept used by EU legislation relating to flight time limitations and minimal rest periods. ${ }^{20}$

For most aircrew, the 'home base' nominated by the air carrier will coincide with the "Member State in which he normally works" as used in the definition of posted workers in Article 2.1 of the Posting of Workers Directive or the concept of "the habitual place of work" as used in Article 8 of the Rome I Regulation ${ }^{21}$ and Article 21 of the Brussels Ibis Regulation. ${ }^{22}$ By way of reminder, Article 8 of the Rome I Regulation allows the contracting parties the freedom to choose the applicable labour law, except for the mandatory provisions of labour law of the employee's habitual place of work when the latter can be identified.

We assume in the evaluation below that the nominated home base is also the de facto home base for most aircrew: his/her habitual place of work. If this is not the case, the chances are great that the air carrier is using the nomination of the home base for social dumping purposes. The fraudulent nomination of a home base which is not the real home base can lead to a multitude of problems, particularly when it comes to identifying the correct rules to be applied. Therefore, it is impor-

18. Regulation (EC) No. $883 / 2004$ of the European Parliament and of the Council of 29 April 2004 on the coordination of social security systems.

19. Annex III to Regulation (EEC) No. 3922/91 provides for common technical requirements and administrative procedures applicable to commercial transportation by aeroplanes.

20. Council Regulation (EEC) No. 3922/91 of 16 December 1991 on the harmonization of technical requirements and administrative procedures in the field of civil aviation, Annex III; Y. Jorens, D. Gilis, L. Valcke and J. De Coninck, 'Atypical forms of employment in the aviation sector', European Social Dialogue, European Commission 2015, p. 26.

21. Regulation (EC) No. 593/2008 of the European Parliament and of the Council of 17 June 2008 on the law applicable to contractual obligations (Rome I).

22. Regulation (EU) No. $1215 / 2012$ of the European Parliament and of the Council of 12 December 2012 on jurisdiction and the recognition and enforcement of judgments in civil and commercial matters (Brussels Ibis). 
tant that this practice is controlled and sanctioned by the authorities.

The de facto home base or habitual place of work, to which we refer in the Report, can be identified with the help of several elements. Some useful indicia were found in the case law, regarding the concept of the habitual place of work in the Brussels Ibis Regulation (most recent, the Cremlink E Ryanair case ${ }^{23}$ ) and the Rome I Regulation:

- the place from which the worker carries out his transport-related tasks,

- the place where he returns after his tasks, receives instructions concerning his tasks and organises his work,

- the place where his work tools are to be found,

- the place where the aircraft aboard which the work is habitually performed is stationed, and

- the place where the 'home base' is located, being understood that its relevance would only be undermined if a closer connection were to be displayed with another place.

Next, there is the concept of secondary base: unlike the home base, the secondary base is not a legal concept. The secondary base is the identifiable location from where the aircrew is de facto working from for a limited period of time during the posting. In a posting situation, the aircrew should be working from a secondary base located in a Member State other than that of the home base. An aircrew worker cannot be posted to a new home base, as he/she cannot be posted to his/her habitual place of work, because this is the place they normally work from. In case the new base becomes a new home base, we are not talking about a posting situation, but about a change of home base, which could bring along a change of applicable employment legislation and social security legislation. To be clear, our concept of secondary base is linked to the aircrew worker and not to the air carrier. Therefore, it should not be confused with operational bases, secondary establishments or secondary hubs of air carriers, which are often distinguished from their main hubs.

In other words, in case of a posting, the aircrew temporarily leaves the home base (= habitual place of work) to work from a secondary base (= temporary place of work) in another Member State. If the new place of work becomes the habitual place of work, there is a new home base and there is no longer any posting situation.

23. CJEU 14 September 2017, C-168/16 and C-169/16, Crewlink \& Ryanair, ECLI:EU:C:2017:688. In this case, the CJEU ruled that the concept of 'place where the employee habitually carries out his work', within the meaning of the Brussels Ibis Regulation, could not be equated with that of 'home base', as this is more of a social security concept. However, the Court also added: 'the concept of 'home base' constitutes nevertheless a significant indicium for the purposes of determining the 'place where the employee habitually carries out his work' unless closer connections were to be displayed with a place other than the "home base'".

\section{Protection if it is not a posting situation}

It is important to keep in mind that even if certain situations of employment of aircrew do not fall under the scope of the Posting of Workers Directive, these aircrew will still be protected by a national legal system determined in accordance with the provisions of, among others, the Rome I Regulation on the applicable employment law and of the Social Security Coordination Regulation (and Brussels Ibis Regulation for jurisdictional matters) and therefore will not be left completely exposed to the will of the air carrier.

Article 8 of the Rome I Regulation will look at the habitual place of work to determine the applicable employment law. This Article can also function as an effective tool against social dumping as it does not allow the parties to deviate from the mandatory provisions of labour law of the habitual place of work.

Further, the important condition that a posting should be temporary (limited period of time, see below) also follows from the Rome I Regulation, as this Regulation states that the applicable employment legislation does not change if the work in another Member State is merely temporary: "The country where the work is habitually carried out shall not be deemed to have changed if he is temporarily employed in another country." 24 In addition, the 36th recital of the Regulation states: "As regards individual employment contracts, work carried out in another country should be regarded as temporary if the employee is expected to resume working in the country of origin after carrying out his tasks abroad." The intention to return is therefore important and it is noticeable that an emphasis is placed on the parties' expectations rather than, for example, time spent in another Member State. ${ }^{25}$

This also indicates that, in case the 'posting' involves a change of the habitual place of work (which should be the home base), there actually cannot be a posting within the meaning of the Posting of Workers Directive as one should not apply only the posting rules (the hardcore labour provisions of the 'hosting' Member State), but the whole employment law of this country.

In case the home base regularly switches (e.g. every two months), one can wonder if it is still possible to identify a habitual - as opposed to temporary - place of work to determine the applicable employment law. This situation is not unknown in the case law. Indeed, the CJEU has ruled ${ }^{26}$ that when the place of work changes regularly, one has to take account of the whole duration of the employment relationship, in order to identify where the employee has worked the longest. Only if it is not possi-

24. Article 8.2 Rome I Regulation.

25. F. Van Overbeeke, Sociale concurrentie en conflictenrecht in het Europees wegtransport, PhD Thesis defended at the University of Antwerp, 2018, p. 227, open access: https://repository.uantwerpen.be/ docman/irua/f21992/155699.pdf.

26. CJEU 27 February 2002, C-37/00, EU:C:2002:122, Weber, § 58. 
ble to do so, the place of hiring of the aircrew will be taken into account, but only if the aircrew does not have a closer link with one of the involved countries. Therefore, it will only be possible to 'evade' the protective rules of the Rome I Regulation by applying the law of the place of hiring if it is impossible to identify the habitual place of work due to regular change and if there is no closer link between the aircrew and any of the countries they worked from.

Similarly, it will only be possible to evade the protective rules of the EU Social Security Coordination Regulation by applying the legislation of the Member State where the employer has its registered office if the home base regularly switches so that Article 11(5) of the Regulation should be disapplied and provided that the aircrew worker does not pursue a substantial part of his/her activities in the Member State of residence by virtue of Article 13.1.b) of the same Regulation, which will often be the case.

In many cases, however, it will be difficult for air carriers to evade the protective rules of the Rome I Regulation and of the Social Security Coordination Regulation as changing the home base of the aircrew regularly could bring with it extensive legal consequences and involve administrative as well as legal costs, e.g. to adapt the terms of the employment contract.

\section{Evaluation of the situations that fall outside the scope of the posting rules}

The following situations with regards to work patterns of aircrew can be considered as excluded from the scope of the posting rules:

\subsection{When there is no posting activity}

This instance is not explicitly mentioned by the Ricardo Study, but it is important to keep the scope of the Posting of Workers Directive in mind, which in Article 1.3 limits its application to:

- undertakings that post workers to the territory of a Member State on their account and under their direction, under a contract concluded between the undertaking making the posting and the party for whom the services are intended, operating in that Member State, provided there is an employment relationship between the undertaking making the posting and the worker during the period of posting (standard posting); or

- undertakings that post workers to an establishment or to an undertaking owned by the group in the territory of a Member State, provided there is an employment relationship between the undertaking making the posting and the worker during the period of posting (intra-group posting); or

- temporary employment undertakings or placement agencies that hire out a worker to a user undertaking established or operating in the territory of a Member State, provided there is an employment relationship between the temporary employment undertaking or placement agency and the worker during the period of posting (temporary agency posting).

Therefore, if it is just the air carrier as an employer who is flying its aircrew to other locations, without any link to other parties or to establishments of the company or undertakings owned by the same group in the territory of a Member State, the Directive is simply not applicable. Most aircrew operating on standard flights ${ }^{27}$ will not fall under the scope of the posting rules. This was confirmed in a Commission Staff Working Document of 2006 which referred to the minutes of a Council Meeting on the Posting of Workers Directive of $1996 .^{28}$

\subsection{Self-employed aircrew workers or contractors (posting only applies to employees)}

More and more air carriers are shifting their employees towards independent forms of employment, especially pilots for whom the status of self-employed is becoming a standard practice. ${ }^{29}$ Of course, this seems the perfect way to avoid the application of the Posting of Workers Directive, and most other EU social rules (except safety provisions). However, national authorities should be very aware of bogus self-employment. ${ }^{30}$

According to the Ricardo Study, around 9\% of the pilots are declared as self-employed. ${ }^{31}$ This number is significantly higher among low cost carriers. The Ricardo Study also made clear that almost all self-employed pilots do not consider that they are free to work for more than one air carrier in parallel $(90 \%)$, and that they have complete flexibility to decide when and how many hours they fly (93\%). ${ }^{32}$ This indicates that there is a major issue with bogus self-employment. Pilots and cabin crew hired through temporary employment agencies or wet leasing companies seem in particular to be often declared as self-employed, while it seems completely at odds with their actual working conditions and the relationship with the air carriers they are working for. ${ }^{33}$

27. A standard flight in this case can be defined as a simple go-and-return flight, operated for the air carrier-employer, from the home base A to location B and immediately or shortly after returning to home base A.

28. EU Commission, Commission Staff Working Document: Commission's services report on the implementation of Directive 96/71/EC concerning the posting of workers in the framework of the provision of services, Brussels, 4 April 2006, SEC(2006) 439, 12, www.europarl.europa.eu/ RegData/docs_autres_institutions/commission_europeenne/sec/ 2006/0439/COM_SEC(2006)0439_EN.pdf; Council document no. 10048/96 SOC 264 CODEC 550, statement no. 3; S. Feenstra, 'Detachering van werknemers in het kader van het verrichten van diensten - het arbeidsrechtelijke kader - Richtlijn 96/71/EG' in Y. Jorens, Handboek Europese Detachering en vrij verkeer van diensten, Brugge, die Keure, 2009, pp. 252-253.

29. Atypical Employment in Aviation Report 2015 and Ricardo Study 2019.

30. Ricardo Study 2019, p. 98.

31. Ricardo Study 2019, p. 101.

32. Ricardo Study 2019, pp. 105-106.

33. Ricardo Study 2019, p. 102. 
Applying the posting rules to true self-employed persons is of course not possible since self-employed workers do not fall under the scope of the Posting of Workers Directive. This exclusion seems logical since selfemployed workers also fall outside the scope of employment law more generally speaking, which the Posting of Workers Directive purports to protect in the hosting Member State. On the other hand, bogus self-employed aircrew are without doubt within the scope of the EU posting rules and should be protected accordingly if social dumping and unfair competition are to be avoided.

In practice, however, there seems to be a substantive problem with bogus self-employment in the EU aviation industry. Even if only $9 \%$ of the pilots are selfemployed their numbers are rising and if the authorities do not intervene we could end up with an industry of precarious workers who are artificially brought outside the scope of employment law. The fact that many temporary employment agencies and wet leasing companies are declaring their aircrew as self-employed also means that there is no level playing field for companies who qualify their aircrew as employees and therefore bear the social costs for these employees. By allowing bogus selfemployment to develop in the aviation sector, national authorities are currently pushing out of the market the companies who rightfully declare their aircrew as employees.

In conclusion, the Posting of Workers Directive is of course applicable to bogus self-employed aircrew, but first the national authorities or courts will have to deal with the qualification issue of the labour relationship between air carrier (or intermediaries) and aircrew. At the moment, the $\mathrm{EU}$ and the national authorities seem to underestimate this problem. The lack of control is allowing air carriers to use false self-employed aircrew which not only fall outside the scope of the posting rules, but also outside the scope of employment law in general.

\subsection{When there is no temporary assignment, but} operation of flights from-to the home base

Most aircrew which operate on standard flights will be excluded from the application of the posting rules, even if the flights are destined for a Member State where the posting undertaking has an establishment or another undertaking of the same group or a user under a service agreement (compare 7.1, below). In our opinion, a simple flight schedule from home base A to location B in another Member State and back to A does not fall under the scope of the Directive as the employment legislation of the home base will continue to be applicable during the flight and even during the time which the aircrew spends in location B.

However, one could argue that an aircrew who flies to another Member State, at first sight, can fall under the definition of Article 2 of the Posting of Workers Directive: "a worker who, for a limited period, carries out his work in the territory of a Member State other than the State in which he normally works". In that respect, the
Ricardo Study states that there is no temporary assignment when there is a journey which starts and finishes at the employee's home base. In this case, it is argued that the law to be applied throughout the journey should be the one of the home base. ${ }^{34}$

Unfortunately, the Directive has not clarified what a "limited period" of time means. But, we agree with the Ricardo Study that the flights from and to the home base do not seem to fit within the concept of a 'temporary assignment', as the aircrew worker is in this case actually not on a temporary assignment somewhere else but just continuing to do his or her regular cross-border work under normal circumstances.

When looking at our criteria of appropriateness (see Introduction, above), it becomes clear that there are good arguments to exclude this 'standard' situation from the scope of the Directive:

- Feasibility: applying a hard core of labour conditions of another Member State every time an aircrew flies to another country is hardly feasible for the employer. It would not only be very complicated for the air carrier and the aircrew, as they would constantly have to switch from applicable hard-core labour conditions, but also for national authorities for whom it would be nearly impossible to control the application and to enforce the rules.

- Legal certainty: the fast variation of applicable (hard-core) labour conditions would be very confusing and would definitely harm legal certainty for all involved actors.

- Fight against social dumping and unfair competition: next to the argument that enforcement would be a nearly impossible task, it seems also more effective if the employment legislation of the home base continues to apply. The application of the posting rules would have little beneficial effects for the fight against social dumping, as these standard situations are usually not problematic from that viewpoint seen the short period of time spent in each country.

The situation becomes more complicated if the flight assignment stretches over multiple days and different locations. By way of example, the aircrew workers fly from home base A to location B in another Member State, then to location C in another Member State, where they stay for one night in a hotel. The next day they fly to location D in yet another Member State and then back to home base A. It is not immediately clear if this series of flights falls under the 'operation of flights from-to the home base' as it is not a simple go-andreturn flight. Furthermore, the series of flights can become more complicated and longer with different stayovers and locations, which would mean that the aircrew would only return to their home base after several days or even a week.

Yet, if we use the same evaluation criteria, the application of the Posting of Workers Directive seems just as or even more problematic than is the case for a simple

34. Ricardo Study 2019, p. 133. 
flight from and to the home base as this would also mean that the applicable (hard-core) labour conditions would constantly change, in a way which is damaging feasibility, legal certainty and the fight against social dumping even more. It is hard to imagine what good would come from applying five or ten different hardcore labour conditions over a period of several days.

An analogy can easily be made with the recent Dobersberger case. This case revolved around the question of whether the provisions of the Posting of Workers Directive are applicable to a situation in which an international train crosses Austria on its way from Budapest (Hungary) to Munich (Germany) and later returns to Budapest. Austria claimed that the Austrian hard-core labour provisions can be applied to the workers of the train as they are posted to Austria, but the AdvocateGeneral disagreed in his opinion of 29 July 2019. ${ }^{35} \mathrm{He}$ stated that the workers on the train should be considered to be 'highly mobile workers' who's place of work is, in reality, immaterial. For the Advocate-General:

(...) it does not matter whether the means of transport on which they carry out their duties happens, at a specific point in time, to be in Hungary, Austria or Germany. Put differently, the entire logic of the country of origin (or posting) and the country of destination does not apply in such a situation, as there is no country of destination: the train departs in Budapest. It comes back to Budapest. If anything, the country of destination is Hungary itself. Country of origin and destination coincide. I fail to see how the situation of the workers of the case at issue differs from those working, say, on the Budapest tram.

The opinion of the Advocate-General in the Dobersberger case seems to follow our logic for the exclusion of flights from-to the home base, if you replace a train ride with a flight.

On 19 December 2019, The Grand Chamber of the CJEU followed its Advocate-General and ruled in this case that a worker cannot be considered to be posted to the territory of a Member State if the performance of his or her work does not have a sufficient connection with that territory. ${ }^{36}$ This interpretation follows in particular from Article 3(2), read in the light of recital 15 of the Posting of Workers Directive, which, in the case of the very limited provision of services in the territory to which the workers concerned are sent, states that the provisions of that Directive on minimum rates of pay and minimum paid annual holidays are not applicable. The 'sufficient connection with the territory of a (host) Member State' is set to become an important criterion for the application of the old and the revised Posting of Workers Directive.

The importance of this criterion was recently confirmed in another Grand Chamber judgement in the Case

35. Opinion of Attorney-General Szpunar of 29 July 2019, C-16/18, ECLI:EU:C:2019:638, Michael Dobersberger, §§ 53-65.

36. CJEU 19 December 2019, C-16/18, ECLI:EU:C:2019:1110, Michael Dobersberger $-v-$ Magistrat der Stadt Wien.
C-815/18 FNV - v - Van den Bosch Transporten BV and Others. ${ }^{37}$ The Court had to answer the question of whether Hungarian and German lorry drivers, who were sent by their German and Hungarian employers to provide services from the Netherlands, were posted workers or not. The drivers received their instructions from a Dutch transport company and they started and finished their work in The Netherlands, but most part of their transport activities were carried out on the territory of other Member States. The Court stated that the national courts should investigate case by case if there is a sufficient connection to the territory of the host Member State. This can be done in the context of an overall assessment of factors such as the nature of the activities carried out by the worker concerned in that territory, the degree of connection between the worker's activities and the territory of each Member State in which the worker operates, and the proportion represented by those activities in the entire transport service. According to the CJEU, drivers executing cabotage transport activities should be qualified as posted workers. "Cabotage" is the transport of goods (or passengers) between two locations in the same Member State by a company from another Member State. Cabotage transport in the case at hand was completely carried out in The Netherlands (mostly by Hungarian drivers), which creates a sufficient connection to the host Member State. In contrast, this is not the case for a driver who merely transits through the territory of a Member State or for a driver who only carries out cross-border transport operations from the Member State where the transport undertaking is established to the territory of another Member State or vice versa.

Therefore, we must conclude that, in retrospect, the Ricardo Study was right to exclude the flights from-to the home base from the application of the posting rules and that it is preferable to maintain the normal application of the legislation of the home base. However, if the series of flights is of such a nature that it becomes hard to speak of a true home base (the aircrew is constantly moving and does not regularly return to the home base), they can be considered as highly mobile workers with the consequences described below.

\subsection{Highly mobile workers}

According to the Ricardo Study, mobile workers are in a temporary and/or precarious situation but are not considered as posted workers because they are not yet integrated in the labour market of the host Member State. The study refers to two documents of the EU Commission to support this view. ${ }^{38}$ However, we fail to see how

CJEU 1 December 2020, C-815/18, ECLI:EU:C:2020:976, Federatie Nederlandse Vakbeweging $-v-$ Van den Bosch Transporten BV and Others.

38. European Commission, 'Aviation: An open and connected Europe for Jobs, Growth, Investment and Global Leadership', 8 June 2017, Press Release, http://europa.eu/rapid/press-release_IP-17-1552_en.htm; European Commission, 'EU Air Carriers by country holding an active operating licence', 16 May 2018, https://ec.europa.eu/transport/sites/ transport/files/

eu_air_carriers_by_country_holding_an_active_operating_licence.pdf. 
this view can be deduced from the documents which do not seem to relate to the employment matters of aircrew. Moreover, it is not very clear what is meant by 'mobile workers'. Directive 2002/15/EC of 11 March 2002 on the organisation of the working time of persons performing mobile road transport activities defines 'mobile workers' quite broadly as "any worker forming part of the travelling staff, including trainees and apprentices, who is in the service of an undertaking which operates transport services for passengers or goods by road for hire or reward or on its own account". 39 This definition is specific for the road transport sector and is of little help to our research as it is too broad. Also the concept of 'mobile workers' used by Advocate-General Szpunar in his opinion in the Dobersberger case $(\mathrm{C}-16 / 18)$ is too broad as this seems to include all international transport workers. $^{40}$

In our opinion, the mobile workers mentioned in the Ricardo Study can refer to aircrew who work long enough from one location to identify a de facto base, but who also do not have one single home base from where they are posted (and where they return to). In fact, the de facto base is also their home base and thus this home base changes very fast (e.g. after each period of two months). This lack of a true home base makes it difficult to apply the posting rules, as there is no clear temporary assignment in another Member State. Also when taking into account the factual elements of Article 4.3 of the Enforcement Directive of 2014, it becomes clear that mobile workers are not in a situation of posting, as they do not fulfil the element (d) that the posted worker returns to or is expected to resume working in the Member State from which he or she is posted after completion of the work or the provision of services for which he or she was posted.

To distinguish these workers from a too broad concept of mobile workers, we call them 'highly mobile workers'. These highly mobile aircrew are continuously moving their home base between Member States and the posting rules do not apply to such a situation. The applicable employment law should be traced down according to the provisions of Article 8 of the Rome I Regulation. In this way, these workers can be in a precarious situation as the lack of clear connection to a Member State (which makes it difficult to identify their habitual place of work) might open the way for a free choice of the applicable legislation by the parties or at most the application of the mandatory legislation of the place of hiring. Both these options often come down to the air carrier choosing the least protective employment law. This situation is certainly problematic, but it cannot be solved by the posting rules. In fact Article 8 of the Rome I Regulation also provides protection for these situations by leaving open the possibility for a judge to identify a closer link between the aircrew and another Member State than the 'chosen one', in which case the mandatory provisions of the employment legislation of the Member State with the closer link would apply. Only in very few cases might it become difficult to apply the protective rules of the Rome I Regulation with the consequence that the place of hiring would determine the applicable law. In these cases, we would be talking about aircrew being assigned to different home bases every couple of months, while making sure that none of these home bases have a close link with the aircrew (for instance, because they stay there the majority of their time, or because it is the Member State where their family lives). It seems to be logistically difficult to arrange such a schedule for all the aircrew. Yet, this practice seems to be gaining ground (e.g. floating pilots, see below). As a result, the EU should monitor this type of arrangement and could consider introducing, for example, a cap on the amount of changes of home base (per year) or a minimum period before one can change a second time from home base during the same year.

In practice, indeed, some air carriers make use of socalled 'floating pilots' or 'mobile pilots' who do not have a fixed home base but are sent to a base where they are needed the most. In this case, the base they are sent to for a month or two or three will be their home base which will change as soon as they are sent to a new location. These pilots can be qualified as highly mobile workers.

Finally, also according to the criteria of appropriateness (see Introduction, above), it seems not the best idea to apply the posting rules to highly mobile workers:

- Feasibility: even more than it was the case for flight from-to the home base, it would not be feasible for air carriers to constantly have to take into account the hard-core labour provisions of every Member State the employee is flying to and staying in. The same arguments of complexity and practical impossibility for all partners return in this situation.

- Legal certainty: the fast variation of applicable (hard-core) labour conditions is very confusing and is definitely harmful for the legal certainty for all involved actors. Moreover, the lack of home base and/or secondary base makes the situation even less clear.

- Fight against social dumping and unfair competition: although these highly mobile aircrew need adequate protection against social dumping practices, applying the posting rules is not the best solution. It would be better to make certain that they are covered by the employment legislation of one Member State with a certain degree of stability, while preventing that air carriers can quasi-unilaterally decide the law applicable to the employment contract. 


\section{Evaluation of the situations that fall within the scope of the posting rules}

In this part we will assess the situations which are identified as in principle falling under the scope of the Posting of Workers Directive. First, there is the general situation of an aircrew who is posted for a limited period of time to the territory of another Member State. This can happen in the framework of a services agreement with another party (air carrier) or the aircrew can be posted to an establishment of the undertaking in the other Member State or to an undertaking of the same group in the other Member State. Next, we will focus on two more specific situations which can make it harder to recognise a posting situation: wet leasing and posting in the context of temporary agency work.

\subsection{In general: aircrew who are temporarily posted to the territory of another Member State}

The first situation is the general and residuary group. It deals with aircrew who are temporarily posted to the territory of another Member State on the employer's account and under its direction and provided there is an employment relationship between the undertaking making the posting and the employee during the period of posting. To be clear, posting does not cover a simple flight to another Member State. A normal flight is not a situation of posting, as seen in the previous part. In contrast, this situation demands a real temporary assignment.

First, this means that for a limited period of time the aircrew will work from a secondary base other than the place where he or she habitually carries out their work from (the home base). Second:

- the posting should be provided in the framemork of a services agreement between the employer of the aircrew (the air carrier making the posting) and the party for whom the services are intended; or

- the posting should happen to an establishment of the undertaking in another Member State or to an undertaking owned by the group in another Member State. ${ }^{41}$

As said before, if there is no such other party or an establishment or undertaking owned by the group, there is no posting. However, very often air carriers will have a sort of establishment or an undertaking within their group at another airport. For example, they will have a ticketing office or a place where their aircrew can rest or will be briefed about flights etc. Therefore, it can be fairly easy to fulfil the second condition.

It is thus mostly the first-mentioned condition, that for a limited period of time the aircrew worker carries out his/her work in the territory of a Member State other than the Member State in which he/she normally

41. See the scope of the Posting of Workers Directive in Article 2. works, which is important. In practice, this means that there will be, on a temporary basis, a nem secondary base for the morker in another Member State. This does not mean that the applicable employment law is changing, as this is merely a temporary assignment and Article 8.2 of the Rome I Regulation clearly states that "the country where the work is habitually carried out shall not be deemed to have changed if he is temporarily employed in another country". But the hard-core rules of the hosting Member State will have to be applied as the Posting of Workers Directive is applicable.

The problem is mostly that there is a grey zone betmeen a temporary assignment to another Member State and a series of flights, in which case the aircrew eventually returns to the home base. Possibly a week or several weeks might pass before the aircrew worker returns to his/her home base. As said before, the Posting of Workers Directive does not define "a limited period of time" and therefore it can be difficult to identify whether it is a posting or just a series of flights without an assignment to a secondary base. Of course, when the series of constantly changing flights is long and the aircrew is barely in his or her 'home base' anymore, one could wonder if the aircrew really does have a home base where he/she returns to and if he or she is not a highly mobile worker, in which case the posting rules would not apply. One can only speak of a posting if the worker is assigned to a secondary base located in another Member State. If not, either the aircrew has no consistent home base (highly mobile worker) or the series of flights should be considered as an operation of flights from-to the home base. In either case, the Posting of Workers Directive is not applicable.

Furthermore, a real temporary assignment should happen for a fixed period of time during which the work of the aircrew will take place from a secondary base. This time period, in principle, cannot be too short, as it would just be considered a series of flights from-to the home base. But it also cannot be too long, as it would not be considered as 'temporary' anymore. It is difficult to put an exact amount of time on the minimum or maximum $^{42}$ duration of a posting. One has to take the context into consideration. ${ }^{43}$ According to the case law of the CJEU, one can look to the frequency, the periodicity, and the continuity of the services. ${ }^{44}$ If during one week the base is effectively changed from the home base A to secondary base airport B in another Member State and basically all the flights during this week are seen as flights from-to this airport B in the other Member State, one can consider this as a posting even if it only lasted one week. However, if airport B is merely the place where the aircrew starts and ends the week, while

42. Except in the light of social security, where the maximum duration of a posting is in principle 24 months.

43. S. Feenstra, 'Detachering van werknemers in het kader van het verrichten van diensten - het arbeidsrechtelijke kader - Richtlijn 96/71/EG' in Y. Jorens, Handboek Europese Detachering en vrij verkeer van diensten, Brugge, die Keure, 2009, pp. 255-256.

44. CJEU 30 November 1955, C-55/94, ECLI:EU:C:1995:411, Gebhard, § 27; CJEU 13 February 2003, C-131/01, ECLI:EU:C:2003:96, § 22. 
flying to and staying in a collection of other locations and Member States, it can be questioned whether this is a true posting, as the aircrew has no real link with the new location (airport B) and there is no effective assignment to a secondary base. In any case, if the temporary assignment takes place for a longer but limited period of time (multiple weeks, months), a real assignment to a secondary base might become easier to identify.

The application of the posting rules to situations of temporary assignments to other Member States, in a case where the workers are temporarily assigned to a secondary base, also seems justified when we look at the criteria of appropriateness (see Introduction, above):

- Feasibility: as said before, a temporary posting should be for a fixed period of time. This makes it possible for the air carriers to foresee the legal consequences of such temporary assignments. As there will be a clear assignment of the aircrew to a secondary base, it does not seem unreasonable to demand the application of the hard-core labour provisions of the Member State where the secondary base is situated. If there is no real assignment to a secondary base or if the duration is too short to make it feasible, there actually is no posting, and so there is no problem with regard to the criterion of feasibility.

- Legal certainty: as demonstrated above, the distinction between this situation and a series of flights from-to the home base or highly mobile workers is not always easy to recognise. However, when there is a genuine case of posting the Posting of Workers Directive should be applied. Therefore, it is important that the stakeholders are given tools to easily identify a posting situation. If this is the case, there is no issue with legal certainty. In fact, the current lack of application of the posting rules by air carriers (and the lack of enforcement by the Member States) is to a large extent due to legal uncertainty as to which situations fall and do not fall within the scope of the posting rules.

- Fight against social dumping: as the Posting of Workers Directive is an important legal tool in the fight against social dumping, not applying the posting rules to the situation of employment described above would be very counterproductive and leave it up to some air carriers to employ the most inexpensive aircrew everywhere and anytime they want, while generating unfair competition with air carriers that do respect the law and prefer to offer their employees decent working conditions.

Next to this general category of posting, there are two more specific cases of posting in the aviation industry that, in principle, fall under the scope of the Posting of Workers Directive.

\subsection{Wet leasing}

The method of wet leasing, by which an air carrier leases an airplane and (a part of the) aircrew to another air carrier, makes it more complicated for everyone to see whether there is a situation of posting of workers or not. However, if we look at the conditions for a posting situation, a wet leasing context can perfectly be qualified as a situation of posting of aircrew provided in the framework of a services agreement between the employer of the aircrew (the air carrier making the posting) and the party for whom the services are intended (the air carrier who is paying the employer to provide the air crew and the plane for its use). As stated in the Ricardo Study, in order to determine if the Posting of Workers Directive is applicable to a particular wet lease agreement, it should be analysed if there is a temporary posting to a different Member State. If the analysis shows that there is no temporary posting but a permanent one or if the aircrew is just providing services for several different countries while not being assigned to a secondary base, the Posting of Workers Directive would not be applicable. $^{45}$

Therefore, an aircrew worker who is not assigned to a secondary base but who is, by way of example, hired for the first time to be employed in his home base in a wet leasing situation, is not a posted worker. In this case, the place where the wet lease contract is executed is the place where the aircrew worker usually carries out his work according to Article 8 of the Rome I Regulation, and therefore the legislation of that home base shall, in principle, apply without any application of the Posting of Workers Directive as there is no temporary assignment in another Member State.

When looking at the criteria of appropriateness (see Introduction, above), it becomes clear that wet leasing might create technical obstacles for the application of the posting rules, but there are enough reasons to overcome these technical obstacles:

- Feasibility: if an air carrier is temporarily wet leasing a plane and aircrew to an air carrier who will operate the airplane and aircrew from a secondary base, it constitutes a posting. Such a wet leasing operation is obviously a legal contract, possibly preceded by serious negotiations between both parties and due diligence exercises to prevent any legal issues with the commercial aspect of the lease. However, the parties should also take into account the social (law) aspects of the lease. This does seem feasible, especially for the air carrier which provides the plane and the aircrew, before concluding the wet lease contract. If necessary, the costs related to the application of the posting rules could be taken into account when negotiating the price of the wet leasing.

- Legal certainty: as said before, it is perfectly possible to identify the situations in which the Posting of Workers Directive applies, even in a wet leasing context, if only stakeholders are provided with the adequate tools to do so. Not applying posting rules to situations of wet leasing, merely because there are multiple actors involved or because the wet leasing contract is very complicated, cannot be accepted.

45. Ricardo Study 2019, pp. 131-132. 
- Fight against social dumping: it would be contrary to both the content and the spirit of the posting rules if the parties (air carriers) of a wet leasing agreement would be allowed to hide behind complicated legal constructions to evade the application of the hard core rules of the hosting Member State.

The situation becomes more complicated when the 'posting' is organised by a company which specialises in the wet leasing of planes and aircrew. Such a company is not a traditional air carrier, but its business model is the wet leasing practice itself. The wet leasing company will usually nominate its place of business as the home base, from where the workers are posted to the client air carriers. However, if the aircrew are not returning to this socalled home base and actually are never connected to this base or working from this base, it will not be possible to call it their home base and there would be no posting situation. In this case, the aircrew could be seen as highly mobile workers. Therefore, it is necessary to investigate the concrete circumstances of the relationship between the place of business of the company and the aircrew.

Just as is the case for temporary employment agencies (see below), the studies and the information that we have received indicate that in practice wet leasing companies find it difficult to apply the posting rules. In general, these are often completely ignored and also A1 declarations are not requested for posted aircrew. More frequently wet leasing companies are declaring their aircrew as self-employed workers so as to bring them outside the scope of the Posting of Workers Directive. This is so even if many of the aircrew are bogus selfemployed, as their working conditions and the relation with the company indicate an employment relationship. But also for aircrew which do have an employment contract, the posting rules are often not applied.

\subsection{Cases of transnational services in the framework of temporary employment agencies or placement agencies}

In this case, the temporary employment agency sends (posts) its aircrew workers to an air carrier to work from a secondary base in another Member State. The temporary employment agency is the posting entity. We will use the term 'temporary employment agency', even if some of these intermediary companies or placement agencies only declare their aircrew as self-employed persons and not as employees.

Some posting situations are difficult to identify because the aircrew are not employed by the air carrier but by temporary employment agencies or placement agencies. However, the fact that the air carrier is not the employer does not change the conclusion that in case of a temporary assignment in another Member State during which the worker is assigned to a secondary base, the Posting of Workers Directive should apply. Using temporary employment agencies with a view to evade the posting rules, as some air carriers seem to do, is not an acceptable practice from a legal perspective.
In general, posting temporary agency aircrew workers to another Member State will fall under the scope of the Posting of Workers Directive. However, there can be exceptions, by way of example when the agency is posting the aircrew to (secondary) bases which change after relatively short intervals (e.g. every two months) to other Member States and the aircrew worker is never really returning to a home base from which he/she would normally work. In this situation, these secondary bases actually correspond to his/her home base which changes after very short intervals. Such a worker is what we called a highly mobile worker and the Posting of Workers Directive does not apply to such a situation.

Likewise, a situation which would resemble the circumstances of the aircrew in the CJEU case regarding Cremlink E Ryanair should not be qualified as falling under the scope of the posting rules. ${ }^{46}$ In this case Ms Nogueira and others, of Portuguese, Spanish or Belgian nationality, concluded, in the course of 2009 and 2010, contracts of employment with Crewlink, a legal person established in Ireland. Each of their contracts of employment provided that those workers would be employed by Crewlink and seconded (posted) as cabin crew with Ryanair. ${ }^{47}$ The employment contracts also specified that their work relationship was subject to Irish law and that the courts of that Member State had jurisdiction over all disputes relating to the performance or termination of those contracts. However, Charleroi (Belgium) was their home base and all their tasks where performed in and out of Charleroi. This case was not about the application of the Posting of Workers Directive, nor about the applicable legislation (Rome I) but about the competent jurisdiction (Brussels Ibis Regulation). The CJEU ruled that the Belgian judge was competent to handle the case, basing its decision on the concept of the habitual place of work. As this same concept is also the core element of Article 8 of the Rome I Regulation, it is evident that the same reasoning can be followed for the application of the (Belgian) employment legislation. ${ }^{48}$ In addition, this means that Crewlink was not posting these aircrew workers from Ireland to Charleroi (their home base), within the meaning of the Posting of Workers Directive: it is not only the Belgian hard-core labour provisions that should be applied, but the full Belgian employment law.

Taking into account the criteria of appropriateness (see Introduction, above), we do not see any serious reason not to apply the posting rules to transnational services in

46. CJEU 14 September 2017, C-168/16 and C-169/16, Crewlink \& Ryanair, ECLI:EU:C:2017:688.

47. This corresponds specifically to the facts for case C-168/16, but not for case C-169/16, in which the aircrew was not hired through an agency but directly by Ryanair.

48. F. Temming, 'The case of Sandra Nogueira and Others v Crewlink Ireland Ltd and Miguel José Moreno Osacar v Ryanair Designated Activity Company. Comment to Court of Justice of the European Union (Second Chamber), judgement of 14 September 2017, Case C-168/16', European Labour Law Journal, 2018, No. 2, pp. 206-215; P. Van Den Bergh, 'Ryanair: missing link tussen Rome en Brussel', Arbeidsrechtjournaal, 2017, No. 2, p. 17 
the framework of temporary employment agencies or placement agencies:

- Feasibility: it is true that it might complicate the application of the posting rules if the employer is not the air carrier who gives the temporary assignment to the aircrew worker but an employment agency which takes over the responsibility of an employer, especially when a client-user wishes to use the agency's aircrew workers in another Member State. However, the agency should be able to apply the posting rules, especially since the revised Posting of Workers Directive provides that the agency must be informed by the user before the commencement of the temporary work in another Member State. ${ }^{49}$ It then becomes possible to integrate the costs for this posting in the price paid by the user. If the air carrier was already using the temporary agency aircrew workers before and then puts them on a temporary assignment from their home base to a secondary base it will be forced, considering this duty of prior information, to discuss the consequences of this use in advance with the temporary employment agency or, even better, it will be led to deal with this matter in the original contract with the agency.

- Legal certainty: as said above, when the agencyemployer analyses the plans of the air carrier-user and sees that the aircrew would be sent to work from a secondary base in another Member State during a temporary assignment, the application of the posting rules is foreseeable. There is no problem with legal certainty, as long as it is clear who is liable for respecting the provisions of the Posting of Workers Directive. This matter could be expressly dealt with in the contract between the commercial partners.

- Fight against social dumping: again, the parties should not be able to hide behind complicated legal constructions of agency work to evade the posting rules. Of course, it can form an extra challenge for the social inspectorates to find out who is the actual posting employer. But this could be overcome through appropriate declaration systems as provided for by the Enforcement Directive and possibly through A1 declarations, combined with a stricter control mechanism.

According to the studies (especially the Ricardo Study) we have consulted and the information we received from the members of our network in all Member States, currently most temporary employment agencies are not applying the posting rules, nor are they requesting A1 declarations for their aircrew. This lack of compliance seems to be closely connected to the widespread use of self-employed aircrew. As stated above, in many situations the aircrew which are now declared as selfemployed workers by the temporary employment agencies are very likely to be false self-employed or bogus self-employed. As a consequence, these temporary aircrew workers are not protected by the posting rules, nor by the rules of the Rome I Regulation, whereas they should be. In addition, temporary employment agencies who declare their aircrew as employees are met with unfair competition. Such practices, which amount to social fraud, should not be tolerated by the EU and the Member States.

\section{Five conditions}

This evaluation above leads us to the five important cumulative conditions which need to be fulfilled in order to fall under the scope of the Posting of Workers Directive:

1. The posted aircrew worker has an employment relationship

The employment relationship of the aircrew can be with an air carrier or with a temporary employment agency. The aircrew worker is not self-employed. There still is an important issue relating to bogus self-employment of aircrew (to which the Directive should apply), but this is not the focus of this research.

2. The posting falls within the framework of Article 1.3 of the Posting of Workers

Directive

The posting should be:

- to another party in the framework of a services agreement (standard posting); or

- to an establishment of the undertaking or to an undertaking of the same group in another Member State (intra-group posting); or

- to a client (user) of a temporary agency posting its workers to another Member State (temporary agency posting).

3. The aircrew is posted under a temporary assignment

We need to take into consideration the context of the assignment to see whether it fulfils the condition that it is for a limited period of time. However, a too short period can often not be qualified as a true posting as it is too short to be seen as an assignment to a secondary base (see condition 4) and a too long period could not be a temporary posting but hide a change of the habitual place of work.

4. The posted aircrew is assigned to a secondary base in a Member State other than where he/she has his/her home base

The posted worker needs to be genuinely assigned to a secondary base. If during the posting the aircrew continues to regularly work from his/her original home base, there might be no posting. If the posting only takes a short time (e.g. a week) and there is no clear secondary base during this period, there is no posting. However, if during this period there is a secondary base 
in another Member State which is clearly used regularly by the posted worker, there is a posting.

5. The aircrew is supposed to return to the home base at the end of the posting

A true posting situation demands that the aircrew is posted from the home base to a secondary base, which does not become the new home base of the aircrew worker. The secondary base and home base cannot be the same location. Article 4.3(d) of the Enforcement Directive of 2014 makes clear that a real posting situation can be recognised by the fact that the posted worker returns to or is expected to resume working in the Member State from which he or she is posted after completion of the work or the provision of services for which he or she was posted. Therefore, if the aircrew is continuously assigned to other bases (for example every two months), without returning (at least in between or regularly) to a well-defined home base, it is doubtful whether the place from where the aircrew is posted is his/her actual home base. In this case, the aircrew is just changing from one home base to another and the posting rules should not be applied. In this case the aircrew should still in principle be protected by the provisions of the Rome I Regulation.

\section{Conclusions}

When looking at the three criteria of appropriateness, it is safe to conclude that it is mostly legal certainty that critically endangers the suitability of the current legal framework for the posting of aircrew. Issues with the other two factors (feasibility and fight against social dumping) are mostly related to or consequences of the lack of legal certainty. The implementation of the Posting of Workers Directive by the different Member States is not very harmonious and the interpretation by the different jurisdictions of the applicability of the posting rules to aircrew is certainly not uniform. As the legal framework, and especially the Posting of Workers Directive, gives little to no indication on the application of the posting rules to aircrew, some Member States have used legal arguments to exclude aircrew from its scope without any legal basis for it. The lack of clear guidelines for the aviation sector (and case law) has created a substantial problem of legal uncertainty which has resulted in the fact that the posting rules are often not applied in the civil aviation industry. It is crystal clear that the current legal framework faces problems and that the status quo is not an option if the EU and the Member States want to improve and protect the actual working conditions of aircrew and if they want to continue the fight against social dumping practices in the aviation sector. Below, we make some recommendations in order to restore the suitability of the legal framework.

\subsection{Using the five conditions}

The suitability of the legal framework for the posting of aircrew may be questioned. The cause of this unfortunate situation is mostly a lack of legal certainty, caused by a lack of specific provisions (mostly at EU level), a multitude of interpretations and different implementations (by the Member States), and a high level of unawareness amongst air carriers and aircrew.

The main factor of legal uncertainty is that it is very difficult to ascertain to which situation of aircrew employment the Posting of Workers Directive should be applied. The Posting of Workers Directive has a general wording and contains no specific rules for aircrew. Further, the provisions on the scope of application of the Directive are rather concise and they are not supported by significant case law of the CJEU.

Therefore, it seems to be the lack of specific clarifications at EU level that allowed the Member States to develop different ideas about the application of the posting rules to aircrew and which created confusion and discussion amongst air carriers, aircrew, legal experts and other stakeholders.

The lack of legal certainty could be reduced by the EU if it made clear to the Member States and stakeholders when the Posting of Workers Directive should be applied, and when it should not. We have evaluated the main situations identified in practice to see whether they should fall under the scope of the posting rules or not. This evaluation has led us to deduce five important cumulative conditions for applying posting rules. It could be useful for the EU to use these conditions as guidelines for the application of the Posting of Workers Directive in the case of aircrew.

\subsection{Creating a new practical guide on the} application of the posting rules

A first possibility would be to clarify these conditions in secondary EU legislation. However, it seems politically impossible to change the text of the Posting of Workers Directive after it has been revised recently in 2018 after years of tough negotiations. Furthermore, the creation of a new directive, containing the specific rules for the posting of aircrew, as has been introduced for international road transport, ${ }^{50}$ is also not very realistic. Even if there would be a political will (of the Commission) and a consensus between the Member States, the process would take a long time and it might open a Pandora's box for other sectors and industries asking for their own specific posting rules.

However, it is not necessary at this stage to reduce the current lack of legal certainty with hard law (secondary EU legislation). We can continue to work perfectly well with the current provisions of the Posting of Workers Directive. They do not need to be changed as appears from the evaluation of the situations which fall and do

50. Directive (EU) 2020/1057 of the European Parliament and of the Council of 15 July 2020 laying down specific rules with respect to Directive 96/71/EC and Directive 2014/67/EU for posting drivers in the road transport sector and amending Directive 2006/22/EC as regards enforcement requirements and Regulation (EU) No. 1024/2012. 
not fall under the scope of the Posting of Workers Directive, which merely relied on the current provisions as interpreted in the case law to identify the correct situations of application/exclusion. However, we cannot expect air carriers, let alone aircrew or other stakeholders, to undertake the same legal reasoning on the basis of the current legal framework without any help. What is necessary are clear EU guidelines on how to interpret the general provisions of the Posting of Workers Directive in the specific case of aircrew. It needs to be clear for the Member States, air carriers, aircrew and for other stakeholders when an employment situation for aircrew is posting and when it is not. This could be done through soft law guidelines, if you think about the EU Commission's recent Practical Guide on Posting of Workers of 2019 or the Practical Guide on the applicable legislation of 2013. ${ }^{51}$ These practical guides are not legally binding instruments. Member States are not obliged to implement them, and they do not have any directly binding legal force vis-à-vis legal subjects.

However, a practical guide should be seen as a helpful interpretation tool of EU legislation. Member States and legal subjects (air carriers, aircrew etc.) could use the guidelines to correctly delineate the scope of the Posting of Workers Directive for their own situation. Although not legally binding, the guidelines would have a certain authoritative value as they would be produced by the EU Commission (possibly with the help of the European Labour Authority, see below) and if they are challenged by legal subjects they could be validated by future case law of the CJEU or by national courts, while adapting to the changing circumstances of the aviation industry in view of their flexibility. The content of such a practical guide should include the five cumulative conditions, and be supported by a description of the different situations mentioned in the Report and by an explanation of the reasons why they fall within or outside the scope of the posting rules. Possibly, it could be useful to give multiple examples of each situation.

When looking at the recent Practical Guide on Posting of Workers, a similar reason for the creation of the guidelines for posting of aircrew can be given as mentioned in this Guide:

This document aims at assisting workers, employers and national authorities in understanding the rules on posting of workers, as they have been revised with the adoption of Directive 2014/67/EU and Directive 2018/957/EU. This understanding is essential to ensure that workers are aware of their rights and that the rules are correctly and consistently applied by national authorities and employers throughout the EU. ${ }^{52}$

51. EU Commission, Practical guide on the applicable legislation in the European Union (EU), the European Economic Area (EEA) and Switzerland, 2013; EU Commission, Practical Guide on Posting of Workers, 2019.

52. EU Commission, Practical Guide on Posting of Workers, 2019, https:// ec.europa.eu/social/BlobServlet?docld=21472\&langld=en, p. 2.
However, the recent Practical Guide on Posting of Workers is far too general to be of help for situations of posting of aircrew. A new practical guide for the posting of aircrew would be preferable by far.

\subsection{Enforcement of the rules by the European} Labour Authority and national authorities In addition, it is important that the Posting of Workers Directive is enforced when it comes to genuine posting situations. This enforcement should not depend solely on the courts but must also be supported by the national authorities (including the national social inspectorates). The national authorities should investigate whether air carriers operating in their territory are applying the posting rules when they need to (next to investigating situations of bogus self-employment). The enforcement by the national authorities is based on a principle of mutual trust between the EU Member States. Unfortunately, the history of the posting rules and of their implementation and the difficulties with the A1 declarations in social security have taught us that cooperation between the national administrations and social inspectorates must improve in order to create a strong enforcement mechanism in the struggle against social dumping. An important step in this direction is the establishment of the European Labour Authority (ELA) under the Juncker Commission, ${ }^{53}$ which is at the moment still setting up its activities (the first coordinated inspection took place in September 2020, focusing on the construction sector ${ }^{54}$ ). The ELA could promote the knowledge and application of a new practical guide on the posting of aircrew among the national social inspectorates and among the air carriers operating in the EU. In addition, it could promote and coordinate common actions of the national social inspectorates to control the application of the posting rules by air carriers, as this does not seem to be a priority of the national authorities at the moment. Therefore, we believe that the ELA can play an important role in the future cooperation between the Member States to tackle the non-application of the posting rules in light of the fight against social dumping. By the same logic, it has an important role to play with regard to the problems of bogus self-employment of aircrew (see below) and addressing the precarious situation of highly mobile workers.

53. Regulation (EU) $2019 / 1149$ of the European Parliament and of the Council of 20 June 2019 establishing a European Labour Authority, amending Regulations (EC) No. 883/2004, (EU) No. 492/2011, and (EU) 2016/589 and repealing Decision (EU) 2016/344; B. Bednarowicz, 'De Europese Arbeidsautoriteit: Een nieuwe actor in de arbeidsmobiliteit', ArbeidJ, 2020, https://ec.europa.eu/transport/sites/transport/ files/

eu_air_carriers_by_country_holding_an_active_operating_licence.pdf; S. Borelli, "“Which way I ought to go from here?" The European Labour Authority in the Internal Market Regulation' in S. Borelli and A. Guazzarotti, Labour Mobility and transnational solidarity in the European Union, Jovene, 2019; J. Cremers, 'The European Labour Authority and rights-based labour mobility', ERA Forum 2020, https://doi.org/ 10.1007/s12027-020-00601-1.

54. ELA, 'The European Labour Authority coordinates its very first concerted inspection', 21 September 2020, www.ela.europa.eu/theeuropean-labour-authority-coordinates-its-very-first-concertedinspection.html. 


\subsection{Confronting the issue of bogus self- employment}

The ELA should take the lead in setting up a coordinated EU-wide control programme to check the incorrect and sometimes fraudulent use of the self-employed status in the EU aviation industry. Of course, the issue of bogus self-employment is not specific to the aviation sector, but the mobile nature of the activities and the complicated and transnational elements of the structures of the companies and of the employment relationships (e.g. the use of wet leasing or intermediary companies such as temporary employment agencies) demand a high level of coordination that is only possible at the EU-level. Many national inspectorates would avoid such actions without European support because of the complexity of the matter and Member States might fear losing air carriers willing to operate on their soil if other Member States are less or not willing to take action, which brings us back to one of the main problems related to social dumping.

\subsection{Dealing with highly mobile aircrew}

Finally, for highly mobile workers for whom, in our view, the Posting of Workers Directive is not applicable, it can be hard to determine the applicable employment law and social security legislation, seen the difficulties in identifying the habitual place of work or a base in a Member State with which the aircrew worker has a closer link. It would be difficult from a logistical perspective for the air carrier or intermediary company to implement a scheme in which it would employ its aircrew in such a way that it systematically falls outside the scope of the Posting of Workers Directive and avoids the protection offered by the Rome I Regulation. Nevertheless, for example with floating pilots, it does seem to be an increasing practice. Therefore, the EU and the Member States should make sure that companies do not exploit such a possibility in order to be able to basically choose the applicable employment legislation (e.g. by using the place of hiring). This could be done by introducing (through secondary legislation) a cap on the amount of changes of home base (per year) or a minimum period before one can change a second time from home base during the same year in order to safeguard a high degree of permanence for the home base. This would be logical as the home base is the place where the aircrew normally starts and ends a duty period or a series of duty periods, which implies that a certain level of stability should be inherent to the home base. 